
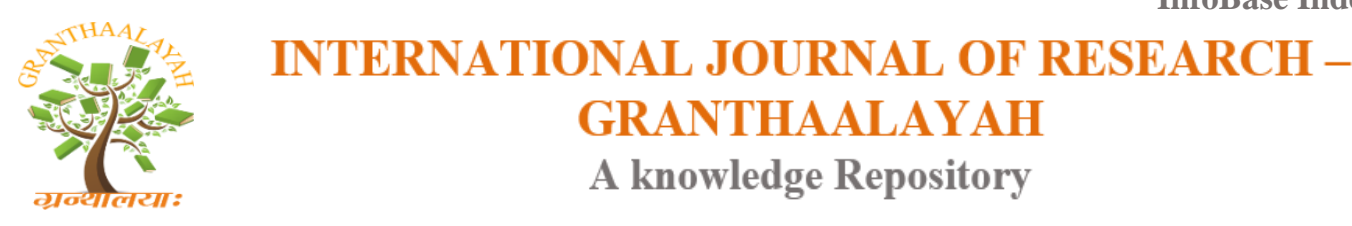

Social

\title{
A STUDY OF SOCIO-CULTURAL FACTORS AS A CORRELATION ON ACHIEVEMENT OF BASIC MATHEMATICAL SKILLS AMONG HIGH SCHOOL STUDENTS
}

\author{
Prakash.P.N*1, Ms.Malathi.V.A ${ }^{2}$ \\ ${ }^{* 1}$ MEd Scholar, RVS College of Education, India \\ ${ }^{2}$ Assistant Professor in Computer Science, RVS College of Education, India
}

DOI: https://doi.org/10.29121/granthaalayah.v5.i6.2017.2054

\begin{abstract}
A Single and his social environment are equally reliant on social and cultural differences impact the intellectual and affective domain of every individual. The difference may be due to variance between their schools, family, communities etc. So socio-cultural pressure on the educational system has been a matter of deep exploration in many countries. Difference in educational attainment may be due to variance in home background parental caring, socio-economic status, family cultural level etc. accomplishment in Mathematics has, become at present the nation concern educationalists, administrators, the public and parents are involved in this problem. The main motive of the study is to study of socio-cultural factors as a correlation on achievement of basic mathematical skills among high school students. This research is undertaken with a view to examining the relationship with socio-cultural factors and achievement of basic mathematical skills of different high school students with a sample size 300. The result concluded that there doesn't exist any relationship between socio-cultural factors and achievement in basic mathematical skills among high school students.
\end{abstract}

Keywords: Socio-Cultural Factors; Achievement; Mathematical Skills.

Cite This Article: Prakash.P.N, and Ms.Malathi.V.A. (2017). "A STUDY OF SOCIOCULTURAL FACTORS AS A CORRELATION ON ACHIEVEMENT OF BASIC MATHEMATICAL SKILLS AMONG HIGH SCHOOL STUDENTS." International Journal of Research - Granthaalayah, 5(6), 447-452. 10.29121/granthaalayah.v5.16.2017.2054.

\section{Introduction}

Being mathematics teacher the investigator is very interested to know about the effect of sociocultural factors on achievement of basic mathematical skills among high school students. It is hoped that the findings of the study be helpful to teacher's parents and educational reformers. That means it will help them to realize that a proper socio-cultural environment is a necessary factor in the mathematical achievement of a student. Parents should take care to create a suitable 
socio-cultural environment in the home parents must try to check regularly the study materials of their children and give them proper directions. Parents should help them to solve mathematics problems. Teachers should motivate the children to participate in mathematics quiz programme. Teachers should provide opportunities to mingle with their peer groups. A co-operative effort of parents and teacher's is essential for the betterment of academic achievement in children.

\subsection{Objectives of the Study}

There are two main types of objectives undertaken by the investigator in this study work.

\subsubsection{General Objectives}

- To study the socio-cultural factors as a correlation on achievement of basic mathematical skills among high school students in Palakkad District.

- To adopt questionnaire on socio-cultural factors among high school students.

\subsubsection{Specific Objectives}

- To study about the socio-cultural environment of high school students.

- To study about the achievement of basic mathematical skills among high school students.

- To find out whether there exists a significant difference on socio cultural factors between male and female high school students.

- To find out whether there exists a significant difference on socio cultural factors between rural and urban high school students.

- To find out whether there exists a significant difference, on socail-culture factors among aided, unaided and govt. high school students.

- To find out whether there exists a significant difference on achievement of mathematical skills between rural and urban area high school students.

- To find out whether there exists a significant difference on achievement of basic mathematical skills among aided, unaided and govt. High school students.

- To find out whether there exists a significant difference on achievement of basic mathematical skills between male and female high school students.

\section{Research Design}

\subsection{Method}

For the present study, normative Survey method is used. A brief description of the sample selected, tools used and statistical techniques used for analyzing the data are as followers:

\subsection{Sample}

The present study was conducted on representative sample of 300 high school students from 8 schools of Palakkad district. Stratified random sampling technique was used, giving due representation to variables like gender, locality and type of school. 


\subsection{Variables of the Study}

This study tries to investigate the correlation of Socio-cultural factors on achievement of basic mathematical skills among secondary school students of Palakkad District.

The Select independent variable is socio-cultural which include

1) Social-cultural environment of home.

2) Social-cultural environment of school

3) Social-cultural environment of society

The department variable is achievement of basic mathematical skills.

Classificatory variables:- Gender and locale are taken as classificatory variables.

\subsection{Tools used for the Collection of Data}

For the present study, the following tools are employed.

a. Questionnaire on socio-cultural factors. (developed by the researcher)

b. Achievement test in basic mathematical skills (developed by the researcher)

Table 1: Component Wise distribution of items in the Socio-Cultural factor Questionnaire.

\begin{tabular}{|l|l|l|l|}
\hline No. & Components & Score & Percentage \\
\hline 1 & Socio-cultural enrollment of home & 10 & $25 \%$ \\
\hline 2 & Socio-cultural enrollment of school & 20 & $50 \%$ \\
\hline 3 & Socio-cultural enrollment of society & 10 & $25 \%$ \\
\hline
\end{tabular}

\subsection{Preparation of Scoring Key}

Socio-cultural factors questionnaire is used for measuring the socio-cultural environment of secondary school students. This questionnaire included 40 items from three areas of sociocultural factors, like socio-cultural environment of home, socio-cultural environment of school, socio-cultural environment of society of the students. Score one is given to each correct responses and zero to wrong responses.

\subsection{Preparation of Question-Wise Analysis.}

In order to avoid all loopholes the investigator prepares a table containing all relevant details of all the items of the test. This is done by making an analysis of each item in terms of content material objective, specification, form of question, difficulty level, marks and estimated time. This help the investigator to check whether all the aspects envisaged in the design and blue print are satisfied by test in its final form.

Table 2: Weightage to objectives

\begin{tabular}{|l|l|l|l|}
\hline No. & Objectives & Marks & Percentage \\
\hline 1 & Knowledge & 7 & $17.5 \%$ \\
\hline 2 & Understanding & 9 & $22.5 \%$ \\
\hline 3 & Application & 7 & $17.5 \%$ \\
\hline 4 & Analysis & 2 & $5 \%$ \\
\hline
\end{tabular}




\begin{tabular}{|l|l|l|l|}
\hline 5 & Skills & 13 & $32.5 \%$ \\
\hline 6 & Synthesis & 2 & $5 \%$ \\
\hline & & 40 & $100 \%$ \\
\hline
\end{tabular}

Table 3: Weightage to Content

\begin{tabular}{|l|l|l|}
\hline Content & Marks & Percentage \\
\hline Basic mathematical skills & 40 & $100 \%$ \\
\hline
\end{tabular}

Table 4: Weightage to form of question

\begin{tabular}{|l|l|l|l|}
\hline Form of question & Number of items & Marks & Percentage \\
\hline Objective & 40 & 40 & $100 \%$ \\
\hline
\end{tabular}

Table 5: Weightage to Difficulty level

\begin{tabular}{|l|l|l|l|}
\hline No. & Difficulty level & Marks & Percentage \\
\hline 1 & Easy & 10 & $25 \%$ \\
\hline 2 & Average & 18 & $45 \%$ \\
\hline 3 & Difficult & 12 & $30 \%$ \\
\hline & Total & 40 & $100 \%$ \\
\hline
\end{tabular}

Table 7: Blue Print

\begin{tabular}{|l|l|l|l|l|l|l|l|l|}
\hline Objectives & Knowledge & $\begin{array}{l}\text { Under } \\
\text { Standings }\end{array}$ & Application & Analysis & Skills & Synthesis & Total & Total \\
\hline $\begin{array}{l}\text { Form of } \\
\text { questions }\end{array}$ & Objective & Objective & Objective & Objective & Objective & objective & & \\
\hline Content & $1(7)$ & $1(9)$ & $1(7)$ & $1(2)$ & $1(13)$ & $1(2)$ & 40 & 40 \\
\hline $\begin{array}{l}\text { Basic } \\
\text { Mathema } \\
\text { tical skills }\end{array}$ & & & & & & & & \\
\hline Total & 7 & 9 & 7 & 2 & 13 & 2 & 40 & 40 \\
\hline
\end{tabular}

Figure outside the bracket indicates the marks and within brackets indicates number of questions

$\mathrm{O}=$ Objective type

$\mathrm{SA}=$ Short answer

$\mathrm{E} \quad=\quad$ Essay

Table 8: Details of schoolwise break, up of final sample.

\begin{tabular}{|l|l|l|}
\hline Sl.No. & Name of school & Locality \\
\hline 1 & KTM High school, Mannarkkad & Urban \\
\hline 2 & Higher secondary school, Sreekrishnapuram & Rural \\
\hline 3 & Govt. Higher secondary school, Cherpulassery & Urban \\
\hline 4 & Govt. Higher secondary school, Alanallur & Rural \\
\hline 5 & B.E.M Higher secondary school,Palakkad & Urban \\
\hline 6 & Higher secondary school, Mundur & Rural \\
\hline 7 & Desabandhu higher secondary school, Thachampara & Urban \\
\hline 8 & Govt. higher secondary school, Pulapatta & Rural \\
\hline
\end{tabular}


HYPOTHESIS 1: There will be significant difference in the mean scores of socio-cultural factors of secondary school students for the sub sample based on gender and locale.

Table 9: Results of the test of significant difference in the mean scores of socio-cultural factors of high school students for the sub sample based on gender.

\begin{tabular}{|l|l|l|l|l|l|}
\hline Variable & Locale & N & Mean & $\begin{array}{l}\text { Standard } \\
\text { deviation }\end{array}$ & Critical ratio \\
\hline \multirow{2}{*}{ Socio-cultural factors } & Urban & 150 & 33.3625 & 5.07992 & $0.285 \#$ \\
\cline { 2 - 6 } & Rural & 150 & 33.4575 & 4.33071 & \\
\hline
\end{tabular}

From the table 9, it is concluded that there exists no significant difference in the mean scores of socio-cultural factors of high school students for the sub sample based on locale.

HYPOTHESIS 2: There will be significant difference in the mean scores of achievement in basic mathematical skills of high school students for the sub sample based on gender and locale

Table 10: Results of significant difference in the mean scores of achievement in basic mathematical skills of high school students

\begin{tabular}{|l|l|l|l|l|l|}
\hline Variable & Gender & N & Mean & $\begin{array}{l}\text { Standard } \\
\text { deviation }\end{array}$ & $\begin{array}{l}\text { Critical } \\
\text { ratio }\end{array}$ \\
\hline $\begin{array}{l}\text { Achievement in basic } \\
\text { mathematical skills }\end{array}$ & Boys & 150 & 16.395 & 6.37853 & $1.438 \#$ \\
\cline { 2 - 6 } & Girls & 150 & 17.0325 & 6.1572 & \\
\hline
\end{tabular}

From the table 10, it is concluded that there exist no significant difference in the mean scores of achievement in basic mathematical skills based on gender.

HYPOTHESIS 3: Test of significance of the correlation coefficients, between socio-cultural factors and achievement in basic mathematical skills of high school students for total sample and sub sample based on gender and locale.

Table 11: Results of significant relationship between the variables among secondary school students for total sample.

\begin{tabular}{|l|l|l|l|}
\hline Sample & Size & $\begin{array}{l}\text { Coefficient of } \\
\text { correlation }\end{array}$ & Critical ratio \\
\hline Total & 300 & 0.048 & $1.3575 \#$ \\
\hline
\end{tabular}

From the table 11, it reveals that for total sample the correlation between the variables sociocultural factors and achievement in basic mathematical skills were found to be 0.048 . This shows that there exist a negligible positive correlation the variables. The calculated t-value (1.3575) is less than the tabled value (1.96 and 2.58) required for significant at 0.05 and 0.01 levels of significance. Therefore ' $r$ ' is found to be not significant.

HYPOTHESIS 4: There will be significant difference in relationship between socio-cultural factors and achievement in basic mathematical skills among high school students for the subsample based on gender and locale. 
Table 12: Results of significant difference in relationship between socio-cultural factors and achievement in basic mathematical skills among high school students based on gender.

\begin{tabular}{|l|l|l|l|l|l|l|l|l|}
\hline $\begin{array}{l}\text { Nature of } \\
\text { sub samples }\end{array}$ & & \multicolumn{2}{|l|}{$\begin{array}{l}\text { Size of the } \\
\text { sample }\end{array}$} & \multicolumn{2}{l|}{$\begin{array}{l}\text { Coefficient of } \\
\text { correlation }\end{array}$} & z-values & t-value \\
\hline \multirow{2}{*}{ Gender } & Boys & $\mathrm{N} 1$ & 150 & $\mathrm{r} 1$ & 0.0263 & $\mathrm{z} 1$ & 0.0263 & $0.708 \#$ \\
\cline { 2 - 10 } & Girls & $\mathrm{N} 2$ & 150 & $\mathrm{r} 2$ & 0.0692 & $\mathrm{z} 2$ & 0.0692 & \\
\hline
\end{tabular}

From the table 11, it reveals that the coefficient of correlation between the variables for boys and girls are 0.0263 and 0.0692 and the z-values are 0.0263 and 0.0692 respectively. The calculated $\mathrm{t}$-value $(0.708)$ is less than the tabled value 1.96 and 2.58. so it can be concluded, that there exists no significant difference between the variables socio-cultural factors and achievement in basic mathematical skills among girls and boys.

\section{Conclusion}

Based on the results obtained from the present study, "A Study of Socio-cultural factors, as a correlate on achievement of basic Mathematical skills among high school students', revealed that there doesn't exist any relationship between socio-cultural factors and achievement in basic mathematical skills among high school students.

\section{Suggestions for Further Research}

1) The study of the effect of socio-cultural factors on achievement in basic mathematical skills can be conducted in VII or VIII standard students.

2) The present study was conducted only one district of Kerala, the study can be conducted on their district of the State.

3) The present study was conducted in Mathematics, the study can be conducted on other subjects.

4) Study can be conducted to find out the factors that causes low achievement in Mathematics.

\section{References}

[1] Ahmed.S.(1980). Effect of Socio-Cultural disadvantages on creative thinking. Journal of psychological Research, 24. 96-106.

[2] Haertel,G.D. Walberg,H.J. \&Haertel, E.H.(1981). Socio-Psychological environments and learning: A quantitative synthesis. British Educational Research Journal, 7, 27-36.

[3] Nair,A.S.(1981). Some Socio-familiar variables causing under achievement in Secondary School Mathematics.Journal of Educational Research an extension, 18, 10-14.

[4] Pandilla,Y.C.(1996). The influence of family background on the educational attainment of Latinos. New England Journal of Public Policy,11(2),25-28.

[5] Sharma,R\&Sharma,D.(1984). A study of the effect of family climate on students academic achievement. Journal of Institute of Educational Research, 8,11-15. 